\title{
MECHANICAL PROPERTIES OF STEEL FIBRE USED CONCRETE PAVING BLOCK
}

\author{
Sachin B. Kandekar ${ }^{1}$, Suresh S. Mandlik ${ }^{2}$, Manesh B. Satpute ${ }^{3}$, Madhukar R. Wakchaure ${ }^{4}$ \\ ${ }^{1}$ Assistant Professor, Civil Engineering Department, Amrutvahini College of Engg., Sangamner, Maharashtra, India \\ ${ }^{2}$ Lecturer, Civil Engineering Department, Amrutvahini Polytechnic, Sangamner, Maharashtra, India \\ ${ }^{3}$ Lecturer, Civil Engineering Department, Amrutvahini Polytechnic, Sangamner, Maharashtra, India \\ ${ }^{4}$ Associate Professor, Civil Engineering Department, Amrutvahini College of Engg., Sangamner, Maharashtra, India
}

\begin{abstract}
Plain concrete is a brittle material. Under impact and dynamic loading plain concrete exhibits extensive cracking and undergoes brittle failure. The concrete is weak in tension and flexure hence to overcome this problem cement concrete, modification in traditional cement concrete has become mandatory. In this modern age, Concrete paving blocks are ideal materials on Open spaces surrounding residential, public, commercial, \& industrial buildings. They are used for the footpaths in the city and walk way in the gardens know a day's paving blocks are also used for light and heavy traffic roads due to their easy laying, better look and finish. In this paper, a parametric experimental study for producing paving blocks using steel fibres is presented

Fibre reinforced concrete (FRC) is defined as concrete made with hydraulic cement, containing fine and coarse aggregate and discontinuous discrete fibre. In FRC, thousands of small steel fibres are dispersed and distributed randomly in the concrete during mixing, and thus improve concrete properties in all directions. FRC is being increasingly used to increase static strength, energy absorbing qualities and better fatigue strength of paving blocks.
\end{abstract}

Keywords: Mechanical Properties, Steel fibers, Paving Block, and Compressive Strength

\section{INTRODUCTION}

The history of Concrete Block Paving (CBP) dates back to 19th Century when paving stones were used in European countries for construction of roads serving as footpaths and tracks for steel-wheeled vehicles. Concrete Block Pavement (CBP), an environment friendly and labour intensive technology, has been developed at CRRI for providing pavements in areas where conventional types of construction are less durable due to many technical and environmental. Cement concrete paving blocks are precast solid products made out of cement concrete. The product is made in various sizes and shapes viz. rectangular, square, and round blocks of different dimensions with designs for interlocking of adjacent paving blocks. The raw materials require for manufactures of the product are Portland cement and aggregates which are available locally in every part of the country.

The study of various research papers it is found that more emphasis is given on concrete used for structural purposes various fibers are added for increasing the properties of structural concrete whereas very less attempts are made to use the fibers in precast concrete paving blocks. As day by day the cost of ingredient material like cement, sand, \& coarse aggregate increasing which affect on the cost of paver blocks, Same is the reason behind present study that to study the effect of steel fibers on strength parameter of concrete paving block. and also to find by using M40 mix of concrete by the use of fibers how much higher strength we are able to achieve, so that cost of high grade concrete will be reduced.
Fibers are usually used in concrete to control cracking due to plastic shrinkage and to drying shrinkage. They also reduce the permeability of concrete and thus reduce bleeding of water. Some types of fibers produce greater impact, abrasion, and resistance in concrete.

This study presents the results of an experimental investigation on M40 grade, Steel fiber reinforced concrete. Hooked end steel fibers are used in this investigation. The effect of these fibers on workability, density and various strengths of concrete are studied. Fiber content varies from 0 to $2.5 \%$ by weight of concrete mass. The various strengths studied in this investigation are compressive strength, flexural strength,and split tensile strength. All the specimens are water cured and tested after 28 days.

\section{LITERATURE REVIEW}

Song and Hwang [1] investigated the mechanical properties of high-strength steel fiber-reinforced concrete. The properties included were compressive and splitting tensile strengths, modulus of rupture, and toughness index. The steel fibers were added at the volume fractions of $0.5 \%$, $1.0 \%, 1.5 \%$, and $2.0 \%$. The compressive strength of the fiber-reinforced concrete reached a maximum at $1.5 \%$ volume fraction, being a $15.3 \%$ improvement over the HSC. The splitting tensile strength and modulus of rupture of the fiber-reinforced concrete improved with increasing the volume fraction, achieving $98.3 \%$ and $126.6 \%$ improvements, respectively, at $2.0 \%$ volume fraction. The toughness index of the fiber-reinforced concrete improved with increasing the fraction. Strength models were 
established to predict the compressive and splitting tensile strengths and modulus of rupture of the fiber-reinforced concrete. The models gave predictions matching the measurements comes content here.

Abid A. Shah , Y. Ribakov [2] used steel fiber. Steel fibered high-strength concrete (SFHSC) became in the recent decades a very popular material in structural engineering. High strength attracts designers and architects as it allows improving the durability as well as the esthetics of a construction. As a result of increased application of SFHSC, many experimental studies are conducted to investigate its properties and to develop new rules for proper design. One of the trends in SFHSC structures is to provide their ductile behavior that is desired for proper structural response to dynamic loadings. An additional goal is to limit development and propagation of macro cracks in the body of SFHSC elements. SFHSC is tough and demonstrates high residual strengths after appearance of the .first crack. Experimental studies were carried out to select effective .fiber contents as well as suitable fiber types, to study most efficient combination of .fiber and regular steel bar reinforcement. Proper selection of other materials like silica fume, .y ash and super plasticizer has also high importance because of the influence on the fresh and hardened concrete properties. Combination of normal-strength concrete with SFHSC composite two-layer beams leads to effective and low cost solutions that may be used in new structures as well as well as for retrofitting existing ones. Using modern nondestructive testing techniques like acoustic emission and nonlinear ultrasound allows verification of most design parameters and control of SFHSC properties during casting and after hardening. This paper presents recent experimental results, obtained in the field SFHSC and non-destructive testing. It reviews the experimental data and provisions of existing codes and standards. Possible ways for developing modern design techniques for SFHSC structures are emphasized.

Vikrant S Vairagade, Kavita S. Kene, Tejas R Patil [3] Concrete is characterized by brittle failure, the nearly complete loss of loading capacity, once failure is initiated. This characteristic, which limits the application of the material, can be overcome by the inclusion of a small amount of short randomly distributed fibers (steel, glass, synthetic and natural) and can be practiced among others that remedy weaknesses of concrete, such as low growth resistance, high shrinkage cracking, low durability, etc. The strength and durability of concrete can be changed by making appropriate changes in its ingredients like cementitious material, aggregate and water and by adding some special ingredients. Hence concrete is very well suited for a wide range of applications. However concrete has some deficiencies as listed below, Low tensile strength, Low post cracking capacity, Brittleness and low ductility, Limited fatigue life, not capable of accommodating large deformations, Low impact strength.
For long term, strength and toughness and high stress resistance, steel fiber reinforced Concrete (SFRC) is increasingly being used in structures such as flooring, housing, precast, tunneling, heavy duty pavement and mining. Generally, aspect ratios of steel fibers used in concrete mix are varied between 50 and 100.The most suitable volume fraction values for concrete mixes are between $0.5 \%$ and $1.5 \%$ by volume of concrete.

1. By addition of $0.5 \%$ hook end steel fibers increases compressive strength of concrete up to $10 \%$.

2. It is observed that, the split tensile strength of fiber reinforced concrete was dependent on length of fiber used. By addition of longer length fiber, the split tensile strength increases.

3. Used of $50 \mathrm{~mm}$ long fiber with same volume of fraction gives $20 \%$ extra split tensile strength over fiber $35 \mathrm{~mm}$ in length.

\section{EXPERIMENTAL WORK}

\subsection{Production of Concrete Mixes}

- Paragraph Production of control mix (normal concrete of grade M-40) in the laboratory is carried out by IS method designed proportions.

- $\quad$ Fiber reinforced concrete is produced by adding steel fibers to the cement concrete.

- $\quad$ Steel fibers were varied from $0.50 \%$ to $2.50 \%$ at a constant interval of $0.50 \%$ by average weight of one cement paving block considered as $5.25 \mathrm{Kg}$ when casted with conventional concrete without fiber.

\subsection{Test Conducted on Material and Paving Block}

The ingredients of concrete i.e. cement, fine aggregate \& coarse aggregate are tested before producing the concrete. The relevant Indian standard codes were followed for conducting various tests on the concrete.

Super plasticizer Sodium Naphthalene Sulphonate based SNF150 by the dosage of $400-850 \mathrm{ml} / \mathrm{bag}$ of cement $(0.8 \%$ to $1.2 \%$ by volume of weight of cement) is used while making the concrete mix to maintain $\mathrm{w} / \mathrm{c}$ ratio.

Casted steel fiber reinforced concrete paving block are cured in water and tested after 28 days. Water absorption, compressive strength, Flexural strength, Abrasion test, and Split tensile strength test on precast concrete paving block are carried out.

\section{RESULT AND DISCUSSION}

\subsection{Water Absorption Test}

The tests were performed on specimen as per Annex-C of IS-15658-2006 using steel fibers. Their water absorption test results are shown in Table-4.1 \& 4.2. 
Table -1: Water absorption test of FRC paving block

\begin{tabular}{|c|c|c|c|c|c|}
\hline $\begin{array}{l}\mathbf{S} \\
\mathbf{N}\end{array}$ & $\begin{array}{l}\% \\
\text { steel } \\
\text { fiber }\end{array}$ & $\begin{array}{l}\text { Wetted } \\
\text { Weight } \\
\text { (kg) Ww }\end{array}$ & $\begin{array}{l}\text { Dry } \\
\text { Weight } \\
\text { (kg)Wd }\end{array}$ & W \% & $\begin{array}{l}\text { Avg } \\
\text { W\% }\end{array}$ \\
\hline \multirow[b]{2}{*}{1} & \multirow{3}{*}{0.00} & 5.86 & 5.54 & 5.78 & \multirow{3}{*}{5.49} \\
\hline & & 5.92 & 5.63 & 5.15 & \\
\hline & & 5.90 & 5.59 & 5.55 & \\
\hline \multirow{3}{*}{2} & \multirow{3}{*}{0.50} & 5.80 & 5.52 & 5.07 & \multirow{3}{*}{5.26} \\
\hline & & 5.84 & 5.54 & 5.42 & \\
\hline & & 5.78 & 5.49 & 5.28 & \\
\hline \multirow{3}{*}{3} & \multirow{3}{*}{1.00} & 5.78 & 5.48 & 5.47 & \multirow{3}{*}{5.40} \\
\hline & & 5.64 & 5.36 & 5.22 & \\
\hline & & 5.74 & 5.44 & 5.51 & \\
\hline \multirow{3}{*}{4} & \multirow{3}{*}{1.50} & 5.86 & 5.52 & 6.16 & \multirow{3}{*}{5.84} \\
\hline & & 5.70 & 5.40 & 5.56 & \\
\hline & & 5.64 & 5.33 & 5.82 & \\
\hline \multirow{3}{*}{5} & \multirow{3}{*}{2.00} & 5.54 & 5.20 & 6.54 & \multirow{3}{*}{6.29} \\
\hline & & 5.80 & 5.50 & 5.45 & \\
\hline & & 5.76 & 5.39 & 6.86 & \\
\hline \multirow{3}{*}{6} & \multirow{3}{*}{2.50} & 5.92 & 5.58 & 6.09 & \multirow{3}{*}{6.50} \\
\hline & & 5.94 & 5.56 & 6.83 & \\
\hline & & 5.84 & 5.48 & 6.57 & \\
\hline
\end{tabular}

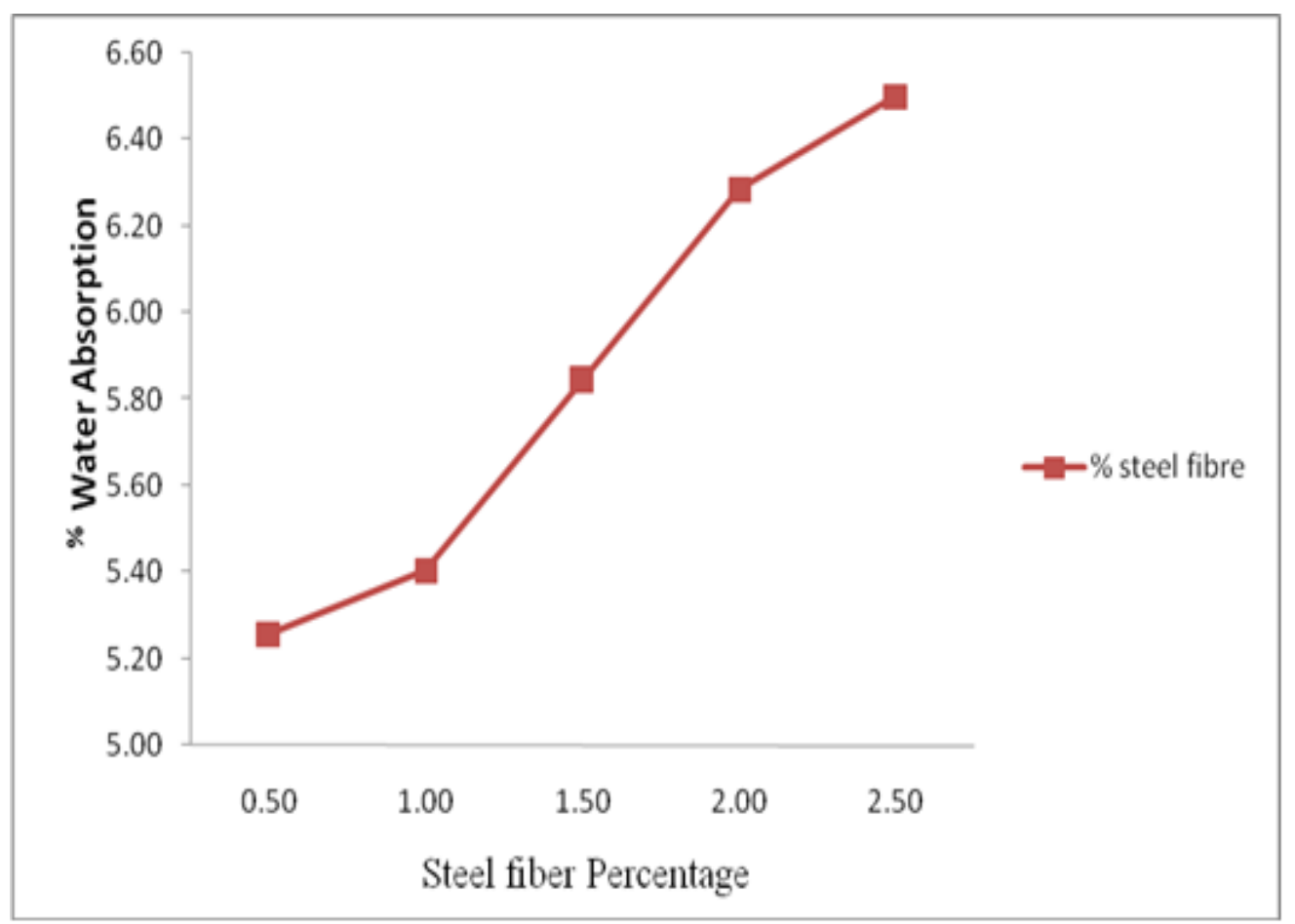

Graph-1: Water absorption of FRC paving block

Results of water absorption test are shown in Table 1 and graph 1 indicates that for steel fibers percentage $0.5 \%$ to $1.50 \%$ gives results up to $6.00 \%$ water absorption .and as percentage of steel fibers increases from $2.00 \%$ \& $2.50 \%$ water absorption found to be $6.29 \%$ \& $6.50 \%$ respectively.

\subsection{Compressive Strength Test}

The tests were performed on specimen as per Annex-D of IS-15658-2006 using steel fibers. Their compressive strength results are shown in Table-4.3 
Table- 2: Compressive strength of Steel Fiber paving block

\begin{tabular}{|c|c|c|c|}
\hline $\mathbf{S}$. & $\begin{array}{l}\% \text { Steel } \\
\text { fiber }\end{array}$ & $\begin{array}{l}\text { Compressive } \\
\text { Strength in MPa }\end{array}$ & $\begin{array}{l}\text { Avg. } \\
\text { Compressive } \\
\text { Strength in MPa }\end{array}$ \\
\hline \multirow{3}{*}{1} & \multirow{3}{*}{0.00} & 53.26 & \multirow{3}{*}{54.93} \\
\hline & & 56.69 & \\
\hline & & 54.83 & \\
\hline \multirow{3}{*}{2} & \multirow{3}{*}{0.50} & 67.30 & \multirow{3}{*}{68.70} \\
\hline & & 70.58 & \\
\hline & & 68.23 & \\
\hline \multirow{3}{*}{3} & \multirow{3}{*}{1.00} & 68.72 & \multirow{3}{*}{73.73} \\
\hline & & 74.12 & \\
\hline & & 78.34 & \\
\hline \multirow{3}{*}{4} & \multirow{3}{*}{1.50} & 75.30 & \multirow{3}{*}{79.45} \\
\hline & & 79.81 & \\
\hline & & 83.25 & \\
\hline \multirow{3}{*}{5} & \multirow{3}{*}{2.00} & 81.48 & \multirow{3}{*}{81.07} \\
\hline & & 80.50 & \\
\hline & & 81.24 & \\
\hline \multirow{3}{*}{6} & \multirow{3}{*}{2.50} & 82.71 & \multirow{3}{*}{86.80} \\
\hline & & 92.23 & \\
\hline & & 85.46 & \\
\hline
\end{tabular}

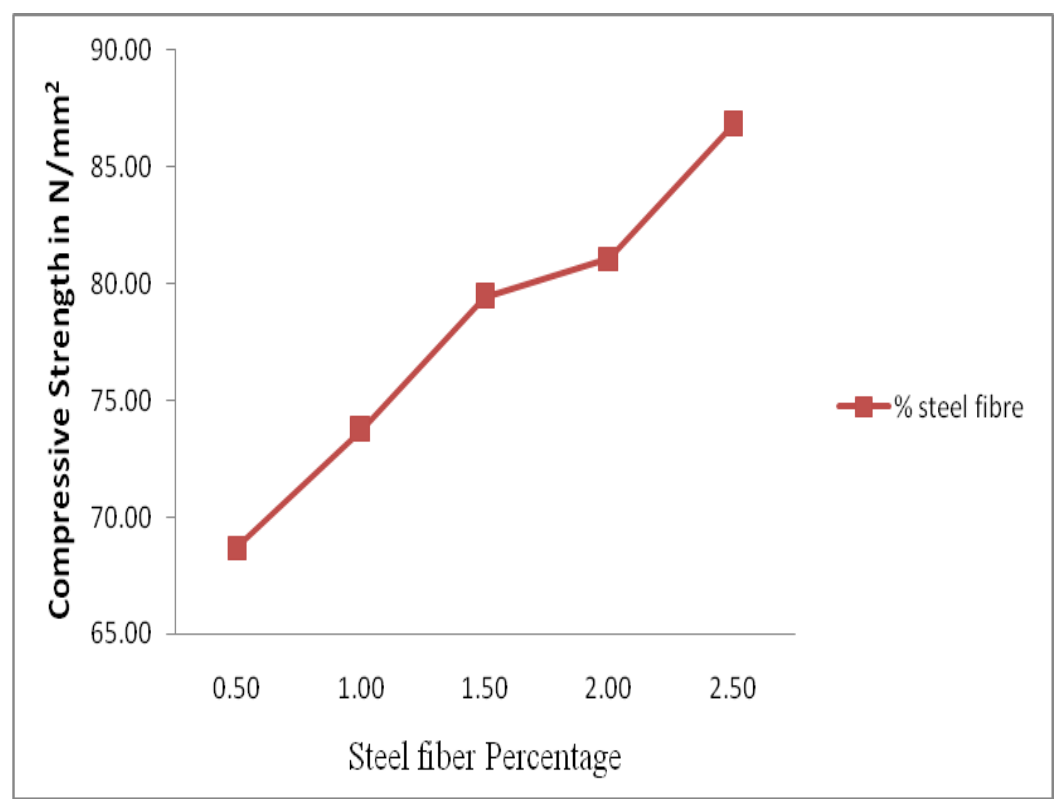

Graph -2: Compressive strength of Steel Fiber paving block

Results of compressive test are shown in Table 2.and graph 2 indicates that strength increases from $68.70 \mathrm{Mpa}$ to $86.80 \mathrm{Mpa}$ with increase in steel fibers from $0.50 \%$ to $2.50 \%$ respectively.

\subsection{Abrasion Test}

The tests were performed on specimen as per Annex-E of IS-15658-2006 using steel fibers. Their abrasion value results are shown in Table-3. 
Table-3: Abrasion value of Steel Fiber used concrete paving block:

\begin{tabular}{|c|c|c|c|c|}
\hline Sr.No & $\begin{array}{l}\% \text { Steel } \\
\text { fiber }\end{array}$ & $\begin{array}{l}\text { Loss in } \\
\text { Volume } \Delta \mathbf{v}\end{array}$ & $\begin{array}{l}\text { Avg. } \\
\text { Wear }\end{array}$ & $\begin{array}{l}\text { Permissible } \\
\text { value } \text { mm }^{3}\end{array}$ \\
\hline \multirow{3}{*}{1} & \multirow{3}{*}{0.00} & 916.67 & \multirow{3}{*}{972.22} & \multirow{3}{*}{1125} \\
\hline & & 958.33 & & \\
\hline & & 1041.67 & & \\
\hline \multirow{3}{*}{2} & \multirow{3}{*}{0.50} & 833.33 & \multirow{3}{*}{861.11} & \multirow{3}{*}{1125} \\
\hline & & 875.00 & & \\
\hline & & 875.00 & & \\
\hline \multirow{3}{*}{3} & \multirow{3}{*}{1.00} & 875.00 & \multirow{3}{*}{791.67} & \multirow{3}{*}{1125} \\
\hline & & 791.67 & & \\
\hline & & 708.33 & & \\
\hline \multirow{3}{*}{4} & \multirow{3}{*}{1.50} & 708.33 & \multirow{3}{*}{750.00} & \multirow{3}{*}{1125} \\
\hline & & 791.67 & & \\
\hline & & 750.00 & & \\
\hline \multirow{3}{*}{5} & \multirow{3}{*}{2.00} & 750.00 & \multirow[b]{3}{*}{736.11} & \multirow[b]{3}{*}{1125} \\
\hline & & 708.33 & & \\
\hline & & 750.00 & & \\
\hline \multirow{3}{*}{6} & \multirow{3}{*}{2.50} & 708.33 & \multirow{3}{*}{708.33} & \multirow{3}{*}{1125} \\
\hline & & 666.67 & & \\
\hline & & 750.00 & & \\
\hline
\end{tabular}

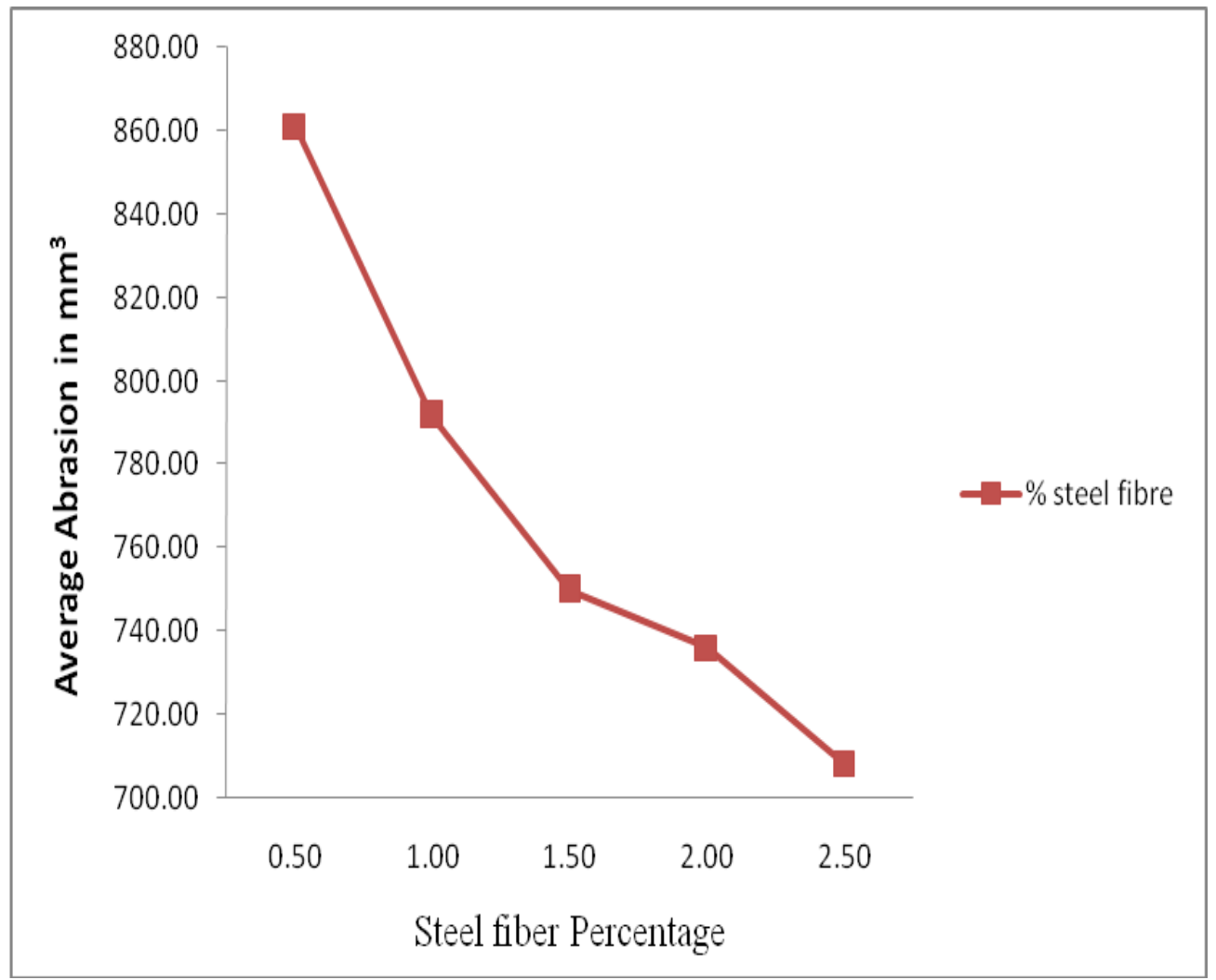

Graph-3: Abrasion value of Steel Fiber used concrete paving block

Results of abrasion test are shown in Table 3 and graph 3 indicates that abrasion value decreases from $861.11 \mathrm{~mm}^{2}$ to $708.33 \mathrm{~mm}{ }^{3}$ with increase in steel fibers from $0.50 \%$ to $2.50 \%$ respectively.

\subsection{Split Tensile Strength:}

The tests were performed on specimen as per Annex-F of IS-15658-2006 using steel fibers. Their split tensile test results are shown in Table-4. 
Table-4: Split Tensile strength of Steel Fiber used concrete paving block:

\begin{tabular}{|c|c|c|c|c|c|c|}
\hline \multirow{2}{*}{$\begin{array}{l}\text { Sr. } \\
\text { No }\end{array}$} & \multirow{2}{*}{$\begin{array}{l}\% \\
\text { Steel } \\
\text { fibre }\end{array}$} & \multicolumn{3}{|c|}{ Dimension } & \multirow{2}{*}{$\begin{array}{l}\text { Split } \\
\text { Strength } \\
\text { Мpa }\end{array}$} & \multirow{2}{*}{$\begin{array}{l}\text { Avg.Split } \\
\text { strength }\end{array}$} \\
\hline & & $\mathbf{L}$ & $\mathbf{S}$ & $\begin{array}{l}\text { C/S } \\
\text { Area }\end{array}$ & & \\
\hline \multirow{3}{*}{1} & \multirow{3}{*}{0.00} & 120 & 80 & 9600 & 1.54 & \multirow{3}{*}{1.57} \\
\hline & & 120 & 80 & 9600 & 1.60 & \\
\hline & & 120 & 80 & 9600 & 1.58 & \\
\hline \multirow{3}{*}{2} & \multirow{3}{*}{0.50} & 120 & 80 & 9600 & 1.72 & \multirow{3}{*}{1.69} \\
\hline & & 120 & 80 & 9600 & 1.66 & \\
\hline & & 120 & 80 & 9600 & 1.69 & \\
\hline \multirow{3}{*}{3} & \multirow{3}{*}{1.00} & 120 & 80 & 9600 & 1.69 & \multirow{3}{*}{1.74} \\
\hline & & 120 & 80 & 9600 & 1.76 & \\
\hline & & 120 & 80 & 9600 & 1.78 & \\
\hline \multirow{3}{*}{4} & \multirow{3}{*}{1.50} & 120 & 80 & 9600 & 1.82 & \multirow{3}{*}{1.79} \\
\hline & & 120 & 80 & 9600 & 1.76 & \\
\hline & & 120 & 80 & 9600 & 1.79 & \\
\hline \multirow{3}{*}{5} & \multirow{3}{*}{2.00} & 120 & 80 & 9600 & 1.87 & \multirow{3}{*}{1.81} \\
\hline & & 120 & 80 & 9600 & 1.79 & \\
\hline & & 120 & 80 & 9600 & 1.78 & \\
\hline \multirow{3}{*}{6} & \multirow{3}{*}{2.50} & 120 & 80 & 9600 & 1.90 & \multirow{3}{*}{1.88} \\
\hline & & 120 & 80 & 9600 & 1.86 & \\
\hline & & 120 & 80 & 9600 & 1.88 & \\
\hline
\end{tabular}

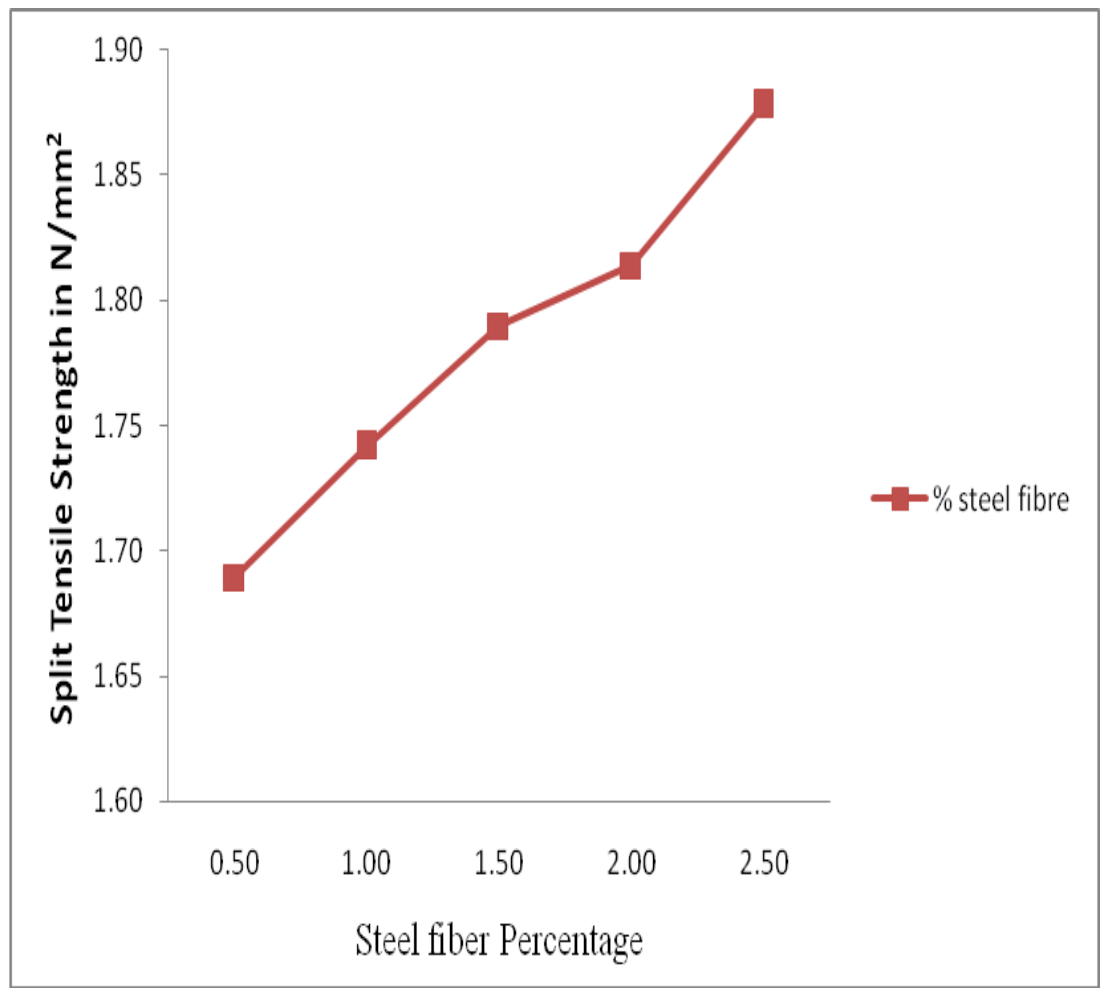

Graph-4: Split Tensile Strength of Steel Fiber used concrete paving block

Results of split tensile test are shown in Table 4 and graph 4 indicates that tensile strength increases from $1.69 \mathrm{Mpa}$ to $1.88 \mathrm{Mpa}$ with increase in steel fibers $0.50 \%$ to $2.50 \%$ respectively.

\subsection{Flexural Strength Test}

The tests were performed on specimen as per Annex-G of IS-15658-2006 using steel fibers. Their flexural strength test results are shown in Table-5. 
Table-5: Flexural strength of Steel Fiber used concrete paving block:

\begin{tabular}{|c|c|c|c|c|c|c|}
\hline \multirow[b]{2}{*}{$\begin{array}{l}\text { Sr. } \\
\text { No }\end{array}$} & \multirow[b]{2}{*}{$\begin{array}{l}\% \\
\text { Steel } \\
\text { fiber }\end{array}$} & \multicolumn{3}{|c|}{ Dimension } & \multirow{2}{*}{$\begin{array}{l}\text { Flexural } \\
\text { strength- } \\
(3 \mathrm{PL} / 2 \mathrm{bd} \\
2 \text { ) in MPa }\end{array}$} & \multirow{2}{*}{$\begin{array}{l}\text { Avg. flexural } \\
\text { Strength } \\
\text { in MPa }\end{array}$} \\
\hline & & $\mathbf{b}$ & d & 1 & & \\
\hline \multirow{3}{*}{1} & \multirow{3}{*}{0.00} & 110 & 80 & 175 & 9.15 & \multirow{3}{*}{9.16} \\
\hline & & 110 & 80 & 175 & 8.77 & \\
\hline & & 110 & 80 & 175 & 9.55 & \\
\hline \multirow{3}{*}{2} & \multirow{3}{*}{0.50} & 110 & 80 & 175 & 15.79 & \multirow{3}{*}{15.69} \\
\hline & & 110 & 80 & 175 & 15.53 & \\
\hline & & 110 & 80 & 175 & 15.74 & \\
\hline \multirow{3}{*}{3} & \multirow{3}{*}{1.00} & 110 & 80 & 175 & 16.86 & \multirow{3}{*}{17.10} \\
\hline & & 110 & 80 & 175 & 17.30 & \\
\hline & & 110 & 80 & 175 & 17.15 & \\
\hline \multirow{3}{*}{4} & \multirow{3}{*}{1.50} & 110 & 80 & 175 & 21.15 & \multirow{3}{*}{20.57} \\
\hline & & 110 & 80 & 175 & 20.28 & \\
\hline & & 110 & 80 & 175 & 20.28 & \\
\hline \multirow{3}{*}{5} & \multirow{3}{*}{2.00} & 110 & 80 & 175 & 21.74 & \multirow{3}{*}{21.58} \\
\hline & & 110 & 80 & 175 & 21.59 & \\
\hline & & 110 & 80 & 175 & 21.43 & \\
\hline \multirow{3}{*}{6} & \multirow{3}{*}{2.50} & 110 & 80 & 175 & 25.88 & \multirow{3}{*}{25.49} \\
\hline & & 110 & 80 & 175 & 25.55 & \\
\hline & & 110 & 80 & 175 & 25.04 & \\
\hline
\end{tabular}

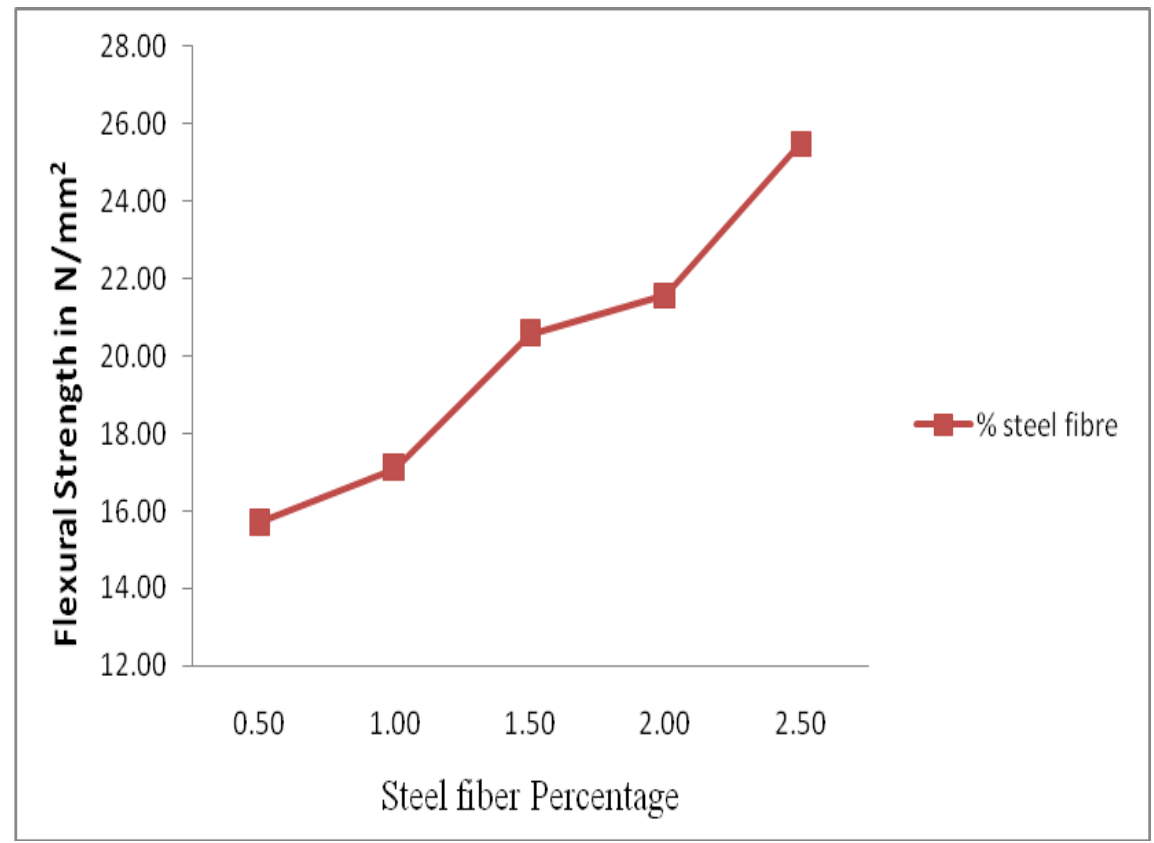

Graph-5: Flexural Strength of Steel Fiber used concrete paving block

Results of flexural strength test are shown in Table 5 and graph 5 indicates that flexural strength increases from 15.69 Mpa to $25.49 \mathrm{Mpa}$ with increase in steel fibers from $0.50 \%$ to $2.50 \%$ respectively. 


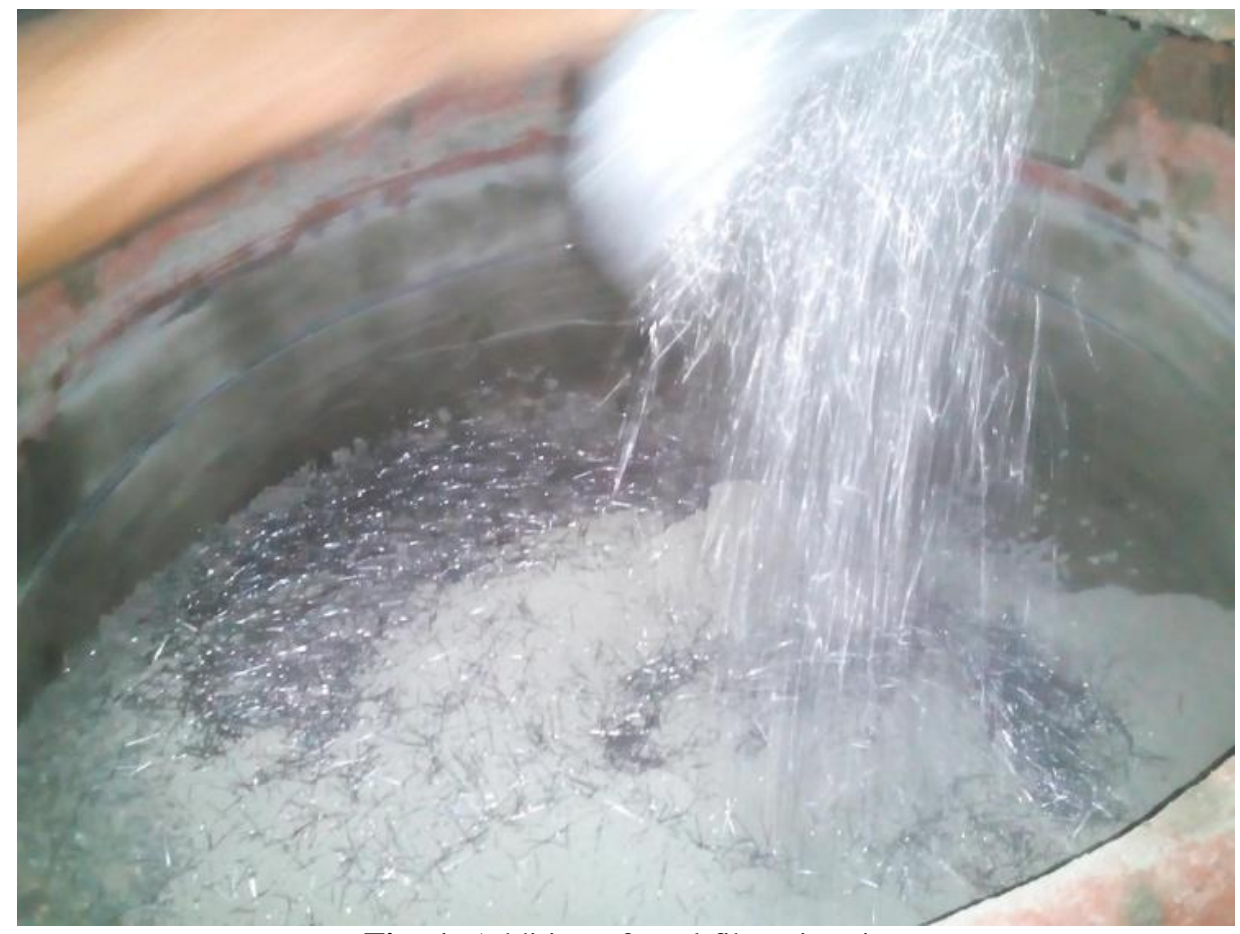

Fig -1: Addition of steel fibers in mix

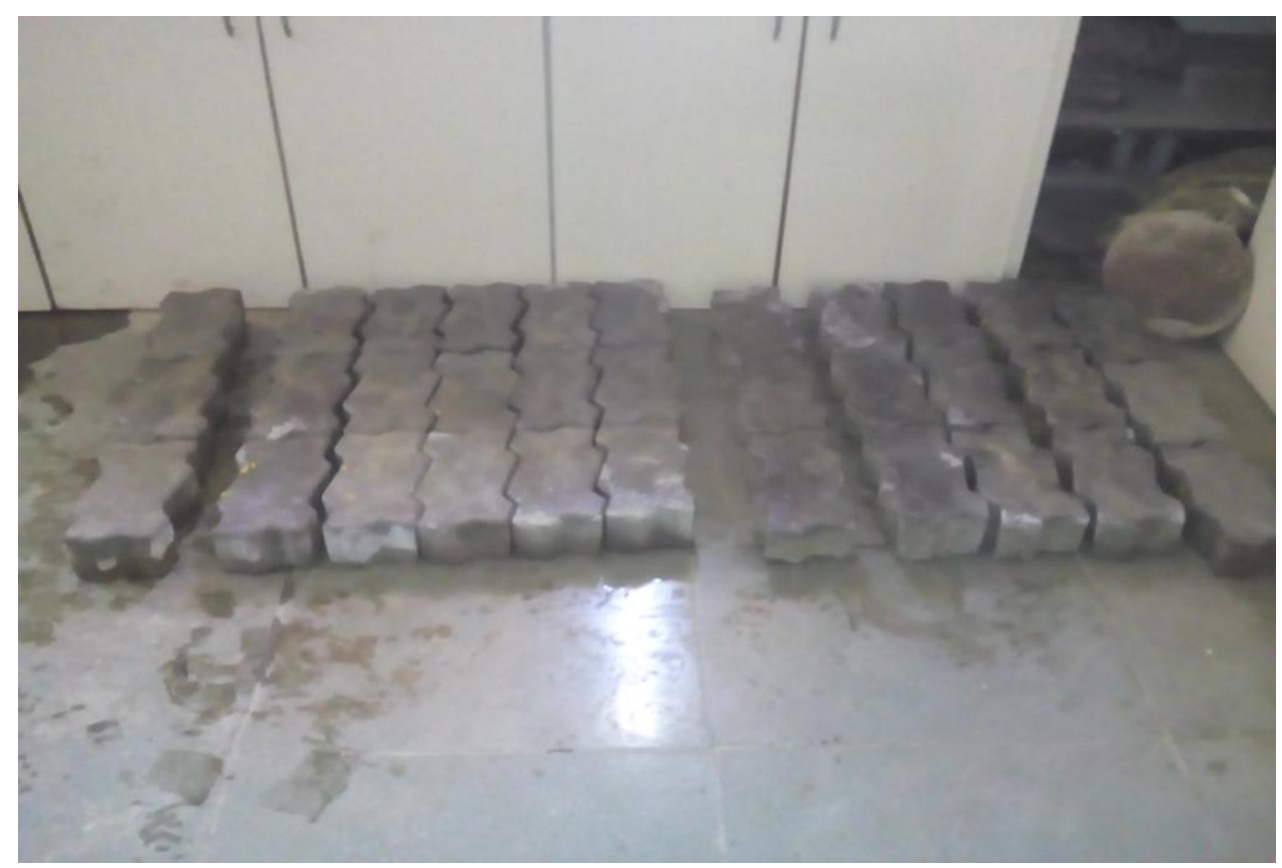

Fig -2: Steel fibers used concrete paving block

\section{CONCLUSION}

Following conclusions are drawn based on the result discussed.

1) Water absorption test indicates that for steel fibers percentage $0.5 \%$ to $1.50 \%$ gives results up to $6.00 \%$ permissible value by IS recommendation for water absorption and as percentage of fibers increases from $2.00 \%$ \& $2.50 \%$ water absorption found more than $6.00 \%$ and increase with increase in fiber percentage. So, the optimum percentage steel fiber mass fraction is $0.50 \%, 1.00 \%$ \& $1.50 \%$.
2) Compressive test indicates that strength increases from 68.70 Mpa to $86.80 \mathrm{Mpa}$ with increase in steel fibers $0.50 \%$ to $2.50 \%$.Hence we can try any percentage of steel fiber ,But from economic point of view $0.50 \%$ steel fibers by mass fraction is desirable.

3) Abrasion test indicates that abrasion value decreases from $861.11 \mathrm{~mm}^{3}$ to708.33 $\mathrm{mm}^{3}$ with increase in steel fibers $0.50 \%$ to $2.50 \%$. Hence we can try any percentage of steel fiber, But from economic point of view $0.50 \%$ steel fibers by mass fraction is desirable. 
4) Split tensile test indicates that tensile strength increases with increase from 1.69 Mpa to $1.88 \mathrm{Mpa}$ with increase in steel fibers $0.50 \%$ to $2.50 \%$. Hence we can try any percentage of steel fiber, But from economic point of view $0.50 \%$ steel fibers by mass fraction is desirable.

5) Flexural strength test indicates that flexural strength increases from 15.69 Mpa to 25.49 Mpa with increase in steel fibers $0.50 \%$ to $2.50 \%$. Hence we can try any percentage of steel fiber,But from economic point of view $0.50 \%$ steel fibers by mass fraction is desirable.

\section{SCOPE FOR FUTURE WORK}

The present work has good scope for future research. Some of the research areas are as follows:

1. Investigation of reduction in cement content for different percentage addition of fibers in mix. when permissible strength results are achieved.

2. Investigation of ductility characteristics of FRC for potential application in seismic design and construction

3. Behaviour under creep and shrinkage.

4. Behaviour of mechanical and physical properties of FRC at various temperatures

\section{ACKNOWLEDGEMENTS}

This paper is completed with the help of many people who had given me their full support and encouragement all the time. However I would like to specially acknowledge and extend my heart full gratitude to few people who made this paper completion possible.

I would like to thank Prof. S. B. Kandekar, Assistant Professor, Civil Engineering, Amrutvahini College of Engineering, Sangamner, who has given me his time, guidance and encouragement to successfully complete the work.

I also like to thank Mr. M. B. Satpute, Lecturer, Amrutvahini Polytechnic, Sangamner, who has given me his time and encouragement to successfully complete the work and publish the paper in research journal.

I would like to show my special gratitude to my parents and friends for their affection and love all the time.

\section{REFERENCES}

[1]. Song and Hwang "Mechanical properties of highstrength steel fiber-reinforced concrete" Construction and Building Materials 18 (2004) 669-673 Available online 17 June 2004.

[2]. Abid A. Shah, Y. Ribakov "Recent trends in steel fibered high-strength concrete" Materials and Design 32 (2011) 4122-415121 March 2011.

[3]. Vikrant S Vairagade, Kavita S. Kene, Tejas R Patil "Comparitive study steel Fiber reinforced concrete" International Journal of Scientific and Research Publications, Volume 2, Issue 5, May 2012.

[4]. Rafat Siddique , Kushal Kapoor , El-Hadj Kadri , Rachid Bennacer "Effect of polyester Fibers on the compressive strength and abrasion resistance of HVFA concrete" Construction and Building Materials 29 (2012) 270-278 Available online 24 November 2011

[5]. Chandramouli K.,Srinivasa RaoP, Pannirselvam N., Seshadri Sekhar T. and Sravana P "Strength Properties Of Glass Fiber Concrete" ARPN Journal of Engineering and Applied Sciences VOL. 5, NO. 4, APRIL 2010.

[6]. Steffen Grünewald and Joost C. Walraven "Parameterstudy on the influence of steel fibers and coarse aggregate content on the fresh properties of self-compacting concrete" Cement and Concrete Research, Volume 31, Issue 12, May 2001, Pages 1793-1798.

[7]. P. Asokan a, Mohamed Osmani b, *, ADF Price b "Improvement of the mechanical properties of glass Fiber reinforced plastic waste powder filled concrete" Construction and Building Materials 24 (2010) 448-460 Available online 10 November 2009

\section{BIOGRAPHIES}

Mr. Sachin B. Kandekar, M.E (Structures), is a civil engineer with 09 years of teaching experience. He is a member in various prestigious societies and professional bodies like ISTE. Presently working as Professor in Department of Civil Engineering, Amrutvahini College of Engineering, Sangamner (M.S). He published many research papers. During his work period he attended many workshops and seminars conducted by various prestigious institutions.

Mr. Suresh S. Mandlik, B.E (Civil), is a civil engineer with 10 years of teaching experience. He has three years professional work experience in Construction industry. Presently working as Lecturer in Department of Civil Engineering, Amrutvahini Polytechnic, Sangamner. $\mathrm{He}$ attended many workshops and seminars conducted by various prestigious institutions.

Mr. Manesh B. Satpute, M.E (Structures), is a civil engineer with 13 years of professional experience. He has two years professional work experience in Construction industry and ten years of teaching experience. Presently working as Lecturer in Department of Civil Engineering, Amrutvahini Polytechnic, Sangamner. He published two research papers on "Effect of fineness on strength of Geopolymer Concrete". During his work period he attended many workshops and seminars conducted by various prestigious institutions.

Prof. Madhukar R. Wakchaure, M.E (Structures), is a civil engineer with 25 years teaching experience. He is a member in various prestigious societies and professional bodies like ISTE. Presently working as Associate Professor in Department of Civil Engineering, Amrutvahini College of Engineering, Sangamner (M.S). He participated in many educational programs in various fields. About 10 papers were published in various esteemed reputable National and International Journals. 